\title{
Degradabilitas Ruminal Secara In Vitro terhadap Pakan Berbasis Bagase Amoniasi dengan Suplementasi Karbohidrat Mudah Tersedia yang Berbeda
}

\author{
In Vitro Ruminal Degradability of Ammoniated Sugarcane Bagasse Based Diet with Different \\ Supplementation of Readily Available Carbohydrate
}

F. Musyafaah, Surahmanto, dan J. Achmadi

Fakultas Peternakan dan Pertanian, Universitas Diponegoro

Corresponding e-mail : fajriyatulmusyafaah59@gmail.com

\begin{abstract}
This study was aimed to clarify the in vitro ruminal degradability of ammoniated sugarcane bagasse based diet (ASBBD) with different supplementation of readily available carbohydrate. The ASBBD containing $12 \%$ crude protein and $60 \%$ total digestible nutrient was supplemented with sugarcane molasses (SM) or banana tree root ball (BTRB). The content of non fibre carbohydrate was similar in both diets. In the in vitro technique, sample of diet was fermented for $48 \mathrm{~h}$ anaerobically using rumen fluid of goat. The parameters were dry matter and organic degradabilities, production of rumen microbe protein and ruminal $\mathrm{pH}$. The ASBBD had similar degradability, production of rumen microbe protein and ruminal $\mathrm{pH}$ when supplemented with sugarcane molasses or banana root ball. The sugarcane molasses could be substituted with banana tree root ball in the ASBBD.
\end{abstract}

Key word : sugarcane bagasse, sugarcane molasses, banana tree root ball, degradability.

\begin{abstract}
ABSTRAK
Penelitian ini bertujuan untuk mengkaji degradabilitas rumen secara in vitro dari pakan komplit berbasis bagasse amoniasi dengan suplementasi karbohidrat mudah tersedia yang berbeda. Pakan komplit yang digunakan mengandung 12\% protein kasar (PK) dan 60\% Total Digestible Nutrient (TDN) dengan suplementasi molases atau tepung bonggol pisang. Pakan komplit dengan suplementasi molasses atau tepung bonggol pisang memiliki kandungan Non Fibre Carbohydrate (NFC) yang sama. Sampel pakan komplit di uji secara in vitro dan difermentasi selama 48 jam secara anaerob dengan cairan rumen kambing. Parameter yang di ukur meliputi degradabilitas bahan kering dan bahan organik, produksi protein mikrobia dan $\mathrm{pH}$ rumen. Pakan komplit berbasis bagasse amoniasi menunjukkan hasil yang tidak berbeda pada degradabilitas bahan kering dan bahan organik, produksi protein mikrobia, dan $\mathrm{pH}$ rumen ketika ditambahkan molases atau bonggol pisang. Tepung bonggol pisang mampu digunakan sebagai substitusi molases dalam pakan komplit.
\end{abstract}

Kata kunci : bagasse, molases, tepung bonggol pisang, degradabilitas.

\section{PENDAHULUAN}

Pemanfaatan limbah pertanian dapat dijadikan sebagai salah satu alternatif untuk memenuhi kebutuhan pakan. Limbah pertanian seperti ampas tebu dapat dimanfaatkan sebagai bahan pakan sumber serat kasar untuk ternak. Bagasse atau ampas tebu merupakan limbah dari hasil penggilingan tebu yang dilakukan secara tradisional maupun berasal dari pabrik pembuatan gula berskala besar. Hasil pengolahan tebu yaitu $30-35 \%$ adalah bagasse. Bagasse dalam pemanfaatannya untuk pakan ternak ruminansia memiliki kendala seperti serat kasar yang tinggi dan kecernaan bahan rendah sehingga perlu dilakukan pengolahan seperti perlakuan alkali, manipulasi rumen dan suplementasi protein pakan (Suryadi, 2008). Amoniasi merupakan salah satu cara pengolahan untuk memperbaiki kualitas bagasse. Amoniasi dapat meningkatkan kandungan nitrogen dalam pakan dan dapat meningkatkan kecernaan pakan. Amoniasi menggunakan urea meupakan salah satu perlakuan alkali yang dapat meningkatkan kualitas pakan berserat tinggi. Amoniasi dapat meregangkan 
ikatan antara lignin dengan selulosa dan hemiselulosa kecernaan bahan pakan tersebut meningkat. Hal tersebut dikarenakan amonia hasil hidrolisis urea dengan bantuan enzim urease akan terikat dalam jaringan (Andayani, 2010).

Pengolahan bagasse dengan cara amoniasi belum cukup untuk memenuhi kebutuhan nutrien ternak sehingga perlu bahan pakan lain yang ditambahkan untuk memenuhi kebutuhan nutrisi ternak. Pembuatan pakan komplit merupakan salah satu alternatif pakan yang dapat diberikan kepada ternak. Pakan komplit adalah pakan dengan kandungan nutrient lengkap yang mampu memenuhi kebutuhan ternak. Pakan komplitmerupakan pakan yang dihasilkan dari campuran pakan hijauan maupun limbah pertanian dengan konsentrat sehingga mempunyai kandungan gizi yang cukup sehingga dapat memenuhi kebutuhan hidup pokok, kebutuhan produksi dan menjadi pakan satu-satunya yang diberikan oleh ternak (Agus et al., 2005).

Pakan komplit dengan komposisi bagasse amoniasi yang cukup tinggi harus diimbangi dengan pakan yang memiliki kandungan karbohidrat mudah terdegradasi. Hal ini dikarenakan bagasse amoniasi mengandung nitrogen yang cukup tinggi sehingga penggunaannya harus diimbangi dengan bahan pakan sumber karbohidrat. Umumnya peternak membuat pakan komplit dengan menggunakan molases sebagai sumber karbohidrat. Molases terdegradasi sempurna pada jam pertama selama inkubasinya dalam rumen (Suhada et al, 2016). Penggunaan molases dikhawatirkan di masa yang akan datang sulit didapatkan sehingga perlu alternatif untuk menggantikan molases. Tepung bonggol pisang merupakan salah satu alternatif bahan pakan sumber karbohidrat yang dapat digunakan dalam pembuatan pakan komplit. Tepung bonggol pisang memiliki kandungan karbohidrat yang tinggi sehingga mampu dijadikan sebagai substitusi molases dalam pembuatan pakan komplit.

\section{MATERI DAN METODE}

Penelitian dilaksanankan selama tiga bulan di Laboratorium Ilmu Nutrisi dan Pakan, Depatemen Peternakan, Fakultas Peternakan dan Pertanian Universitas Diponegoro Semarang.

Pelaksanaan penelitian terdiri atas tiga tahapan yaitu tahap persiapan, perlakuan dan pengambilan data.

\section{Tahap Persiapan}

Tahap persiapan yaitu menyiapkan bahan pakan yang akan digunakan yaitu bekatul, onggok, jagung giling, tepung bonggol pisang dan bagasse amoniasi. Tepung bonggol pisang yang digunakan diambil dari pohon pisang bagian akar yang tidak terlihat dari permukaan tanah. Bonggol pisang yang sudah diambil selanjutnya dicacah kemudian digiling dan dikeringkan dibawah sinar matahari. Bonggol pisang yang sudah kering selanjutnya dihaluskan sampai berbentuk tepung. Metode yang digunakan dalam pembuatan amoniasi yaitu bagasse dikering udarakan terlebih dahulu, selanjutnya bagasse dipotong-potong ukuran $5-10 \mathrm{~cm}$. Urea ditimbang sebanyak 4\% amonia dalam BK bagasse, kemudian urea dilarutkan dalam air, setelah itu larutan urea dan bagasse dicampur sampai merata seluruhnya. Campuran tersebut dimasukkan ke dalam trashbag dan dipadatkan, lalu ditutup dan ditunggu sampai 3 minggu. Bagasse yang sudah di amoniasi kemudian diangin-anginkan dan dihaluskan untuk siap dijadikan sebagai bahan pakan penyusun. Pakan terdiri atas dua formulasi, yaitu pakan dengan bonggol pisang dan pakan dengan molases, disusun PK 12\% dan TDN 60\%.

\section{Tahap Perlakuan}

Penelitian ini membandingkan dua formulasi pakan komplit yang berbeda dengan PK 12\% dan TDN 60\%. Pakan komplit disusun dengan sumber karbohidrat yang berbeda yaitu tepung bonggol pisang dan molases.

$\mathrm{T} 1:$ (pakan + molases $)$

T2 : (pakan + tepung bonggol pisang). 
Tabel 1. Komposisi Ransum

\begin{tabular}{lcc}
\hline \multirow{2}{*}{ Bahan Pakan } & \multicolumn{2}{c}{ Perlakuan } \\
\cline { 2 - 3 } & T1 & T2 \\
\hline Bagasse Amoniasi & $-------\%$------- \\
Bekatul & 55 & 55 \\
Jagung & 20,35 & 21 \\
Onggok & 5 & 5 \\
Tepung Bonggol & 17 & 17 \\
Pisang & 2,65 & - \\
Molases & - & 2 \\
\hline Total & 100 & 100 \\
\hline
\end{tabular}

\begin{tabular}{lll}
\hline \multicolumn{2}{l}{ Kandungan Nutrien } & \\
PK & 12,81 & 12,83 \\
TDN & 60,57 & 60,72 \\
SK & 30,79 & 30,49 \\
NDF & 60,26 & 57,99 \\
NFC & 18,75 & 18,93
\end{tabular}

Protein Kasar (PK), Total Digestible Nutrient (TDN), Serat kasar (SK), Neutral Detergent Fiber (NDF), Non Fibre Carbohydrate (NFC).

\section{Tahap Pengambilan Data}

Pengambilan data dilakukan dengan melakukan analisis $\mathrm{pH}$, protein mikrobia, degradabilitas bahan kering dan bahan organik. Data yang sudah diperoleh dianalisis menggunakan Uji T.

\section{Uji pH}

Bahan yang akan digunakan dikeringkan dan digiling halus dengan ukuran $2 \mathrm{~mm}$ diambil sebanyak $0,55-0,56 \mathrm{~g}$ dan dimasukkan ke dalam fermentor, lalu ditambahkan 1 bagian cairan rumen yang berasal dari kambing berfistula berumur 2 2,5 tahun dengan pakan daun-daunan dan 4 bagian larutan McDougall sebanyak $50 \mathrm{ml}$. Selanjutnya tabung tersebut dialirkan gas $\mathrm{CO}_{2}$. Setelah tabung ditutup ditempatkan pada waterbath dan difermentasi selama 48 jam pada suhu $39^{\circ} \mathrm{C}$, upaya untuk mengetahui fermentabilitas pakan komplit berbasis bagase hasil amoniasi dilakukan pengukuran derajat keasaman $(\mathrm{pH})$ dengan pH meter.

\section{Protein Mikrobia}

Residu hasil inkubasi fermentasi mikrobia rumen disentrifuse dengan dengan kecepatan $3.000 \mathrm{rpm}$ selama 15 menit. Supernatan yang diperoleh digunakan untuk analisis protein mikrobia rumen. Konsentrasi protein mikrobia diukur menggunakan metode Lowry (Plumer, 1971).

\section{Degradabilitas Bahan Kering dan Bahan Organik}

Uji degradabilitas bahan kering dan bahan organik dilakukan menurut metode Tilley dan Terry (1963).

\section{Analisis Data}

Data yang diperoleh kemudian dianalisis menggunakan statistik uji banding yaitu dengan menggunakan Uji T.

\section{HASIL DAN PEMBAHASAN}

\section{Nilai pH}

Berdasarkan hasil analisis statistik terhadap nilai $\mathrm{pH}$ pada perlakuan $\mathrm{T} 1$ dan $\mathrm{T} 2$ menunjukkan hasil yang tidak berbeda nyata $(\mathrm{P}>0,05)$. Ransum yang disusun untuk $\mathrm{T} 1$ dengan penambahan bonggol pisang maupun ransum T2 dengan penambahan molasses memiliki kandungan energi yang sama dapat dilihat dari kandungan TDN ransum yang disusun.

Tabel 2. Hasil penelitian

\begin{tabular}{lcccc}
\hline \multirow{2}{*}{ Parameter } & \multicolumn{2}{c}{ Perlakuan } & \multicolumn{2}{c}{ SEM } \\
\cline { 2 - 5 } & $\mathrm{T} 1$ & $\mathrm{~T} 2$ & $\mathrm{~T} 1$ & $\mathrm{~T} 2$ \\
\hline $\mathrm{pH}$ & 6,6 & 6,6 & 0,05 & 0,04 \\
Protein Mikrobia (mg/g) & 309,92 & 296,41 & 23,44 & 11,07 \\
Degradasi Bahan Kering (\%) & 72,85 & 68,34 & 2,89 & 2,43 \\
Degradasi Bahan Organik(\%) & 60,13 & 56,74 & 2,69 & 1,68 \\
\hline
\end{tabular}

$\mathrm{SEM}=$ Standard Error Mean 
Pada Tabel 2. menunjukkan bahwa nilai $\mathrm{pH}$ pada $\mathrm{T} 1$ yaitu 6,6 dan pada $\mathrm{T} 2$ yaitu 6,6. $\mathrm{pH}$ merupakan derajat keasaman yang digunakan untuk menyatakan tingkat keasaman. Asam yang diproduksi oleh rumen berasal dari aktivitas fermentasi mikrobia rumen terhadap pakan terutama pakan sumber energi. Hidrogen terbentuk dari aktivitas fermentasi pakan menjadi VFA dalam rumen. $\mathrm{pH}$ dapat turun secara cepat apabila pakan mudah terfermentasi karena hidrogen mudah terakumulasi. Pakan dengan kandungan amilum yang tinggi akan lebih cepat menurunkan $\mathrm{pH}$ dikarenakan hidrogen lebih mudah terakumulasi. Hal ini sesuai dengan pendapat Church (1988) yang menyatakan bahwa $\mathrm{H}_{2}$ meningkat seiring dengan bertambahnya asam lemak dalam rumen, hal tersebut menyebabkan konsentrasi hidrogen tinggi. Hal tersebut akan mengakibatkan $\mathrm{pH}$ dalam rumen turun. Orskov (1992) menyatakan bahwa penurunan $\mathrm{pH}$ rumen menghambat mikrobia untuk bertahan hidup sehingga menurunkan populasi mikrobia proteolitik.

$\mathrm{pH}$ rumen yang ideal akan mendukung aktivitas mikrobia dalam rumen. Nilai $\mathrm{pH}$ pada T1 maupun T2 menunjukkan hasil dalam kisaran normal yaitu 6,6. Suryadi (2008) menyatakan bahwa mikrobia membutuhakn $\mathrm{pH}$ tertentu untuk aktivitas dalam rumen, kondisi ideal untuk pertumbuhan mikrobia selulolitik yaitu pada rumen dengan $\mathrm{pH}$ berkisar $6,5-7,0$. Darwis dan Sakura (1990) menyatakan bahwa proses fermentasi di dalam rumen dipertahankan oleh karena adanya sekresi saliva yang berfungsi mempertahankan nilai $\mathrm{pH}$ pada kisaran 6,5-7,0.

\section{Sintesis Protein Mikrobia}

Berdasarkan hasil analisis statistik menunjukkan bahwa produksi protein mikrobia pada T1 tidak berbeda nyata dengan produksi protein mikrobia pada $\mathrm{T} 2$ $(\mathrm{P}>0,05)$. Hal ini dapat disebabkan karena ransum yang disusun memiliki kandungan PK dan TDN yang sama (Tabel 1). Persentase NFC (Non Fiber Carbohydrate) yang disusun dari bonggol pisang maupun molasses juga sama yaitu sebesar 9,53\% dan 9,62\% dalam ransum. Kandungan PK dan TDN yang sama dalam ransum T1 maupun T2 akan mengakibatkan produksi protein yang hampir sama yaitu $309,92 \mathrm{mg} / \mathrm{g}$ pada T1 dan 296,41 mg/g pada T2.

Protein mikrobia terbentuk dari kemampuan mikrobia rumen dalam melakukan sintesis protein mikrobia, sumber $\mathrm{N}$ dan kerangka karbon diperlukan dalam sintesis protein mikrobia. Broudiscou et al., (2003) menyatakan bahwa meningkatnya suplai $\mathrm{NH}_{3}$ pakan akan meningkatkan ketersediaan $\mathrm{N}$ untuk pertumbuhan mikrobia rumen. Kerangka karbon diperoleh oleh mikrobia melalui deaminasi asam amino. Chizzotti et al., (2008) menyatakan bahwa pertumbuhan mikrobia dipengaruhi oleh $\mathrm{NH}_{3}$ rumen dan tingkat fermentabilitas dari pakan. Produksi $\mathrm{NH}_{3}$ rumen yang tinggi memerlukan sumber energi mudah difermentasi untuk mendukung sintesis protein mikrobia yang optimum (Meng et al., 2000).

Aktivitas mikrobia dipengaruhi oleh kondisi rumen, dalam hal ini kondisi rumen dapat dilihat dari nilai $\mathrm{pH}$ rumen. Nilai $\mathrm{pH}$ yang sama pada T1 maupun T2 ( Tabel 2) menyebabkan aktivitas mikrobia yang tidak berbeda nyata sehingga produksi protein mikrobia pada T1 maupun T2 juga tidak berbeda nyata. Menurut Church (1988), pada $\mathrm{pH}$ normal protease dari mikrobia dapat menghidrolisis protein menjadi peptidapeptida dan asam amino bebas dan selanjutnya digunakan oleh mikrobia lain untuk dirombak menjadi amonia dan asam $\alpha$ keto yang selanjutnya dirombak menjadi VFA. Degradasi protein ruminal menurun seiring dengan penurunan $\mathrm{pH}$. Muslim et al. (2014) menyatakan bahwa protein mikrobia rumen merupakan biomassa sumber utama nitrogen untuk ternak. Peningkatan protein mikrobia dipengaruhi oleh faktor lingkungan yang beragam dan faktor populasi bakteri. 


\section{Degradabilitas Bahan Kering dan Bahan Organik}

Berdasarkan hasil analisis statistik menunjukkan hasil bahwa degradabilitas bahan kering pada $\mathrm{T} 1$ tidak berbeda nyata $(\mathrm{P}>0,05)$ dengan degradabilitas bahan kering pada T2. Hasil analisis statistik juga menunjukkan bahwa degradabilitas bahan organik pada $\mathrm{T} 1$ tidak berbeda nyata $(\mathrm{P}>0,05)$ dengan degradabilitas bahan organik pada T2. Hal tersebut dapat dikarenakan aktifitas mikrobia yang sama sehingga hasil yang ditunjukkan juga tidak berbeda. Aktifitas mikrobia rumen yang sama dipengaruhi juga oleh kondisi lingkungan rumen yang dapat dilihat dari nilai $\mathrm{pH}$ rumen. $\mathrm{pH}$ rumen yang sama mengakibatkan aktifitas mikrobia rumen sama sehingga degradablitas bahan kering juga tidak berbeda yaitu sebesar $72,85 \%$ pada T1 dan $68,34 \%$ pada T2. Degradabilitas bahan organik menunjukkan hasil yang tidak berbeda yaitu $60,13 \%$ pada T1 dan $56,74 \%$ pada T2.

Kandungan nutrien dalam pakan akan mempengaruhi aktifitas mikrobia rumen sehingga hal tersebut juga akan berpengaruh terhadap kecernaan pakan pada ternak. Suhartanto et al. (2000) menyatakan bahwa faktor yang dapat mempengaruhi tinggi rendahnya degradasi pakan oleh mikrobia rumen yaitu kandungan nutrien bahan pakan yang digunakan, sehingga hal tersebut dapat mempengaruhi kecernaan pakan pada ternak terutama kandungan ligninnya. Nilai dari degradasi bahan kering menunjukkan besarnya zat makanan dalam pakan dapat dimanfaatkan oleh mikrobia rumen (Sutardi, 1980). Menurut Syahrir (2012), bahwa semakin tinggi degradasi bahan kering dan bahan organik pakan maka semakin tinggi nutrien yang dapat digunakan untuk memenuhi kebutuhan nutrisi ternak.

Degradabilitas bahan dipengaruhi oleh aktivitas mikrobia rumen, semakin tinggi aktivitas mikrobia rumen maka degradabilitas bahan juga akan semakin baik. Hal tersebut juga harus didukung dengan kondisi lingkungan rumen yang ideal yaitu $\mathrm{pH}$ yang sesuai untuk aktivitas mikrobia rumen. Penurunan sintesis mikrobia rumen akan menurunkan aktivitas degradasi maupun fungsi fermentasi mikrobia terhadap pakan. Rahmadi et al., (2010) menyatakan bahwa degradasi bahan pakan pada ternak ruminansia erat hubunganya dengan jumlah protein mikrobia dalam rumen. Suasana rumen yang kondusif, selain dapat meningkatkan populasi mikrobia rumen juga merupakan faktor internal yang dapat meningkatkan degradasi bahan kering pakan. Bahan organik merupakan bagian dari bahan kering hal ini menyebabkan keduanya saling berkaitan satu sama lain. Menurut Zain et al., (2005) menunjukkan bahwa peningkatan kecernaan ataupun fermentabilitas pakan berhubungan dengan pertumbuhan bakteri yang lebih baik. Peningkatan pertumbuhan baketri selulolitik akan tercermin dari degradabilitas bahan organic pakan. Broudiscou et al., (2003) menyatakan, peningkatan sintesis biomassa mikrobia mampu meningkatkan degradabilitas bahan organik pakan.

\section{KESIMPULAN}

Nilai $\mathrm{pH}$, produksi protein mikrobia, degradabilitas bahan kering dan bahan organik pada ransum $\mathrm{T} 1$ dengan penambahan tepung bonggol pisang dan pada ransum T2 dengan penambahan molasses menunjukkan hasil yang tidak berbeda sehingga bonggol pisang dapat digunakan sebagai substitusi molasses.

\section{DAFTAR PUSTAKA}

Agus, A., B. Swignyo., dan R. Utomo. 2005. Penggunaan complete feed berbasis jerami padi fermentasi pada sapi Australian commercial cross terhadap konsumsi nutrien dan pertambahan bobot badan harian. Buletin Peternakan. 29 (1) : $1-9$.

Andayani, J. 2010. Evaluasi kecernaan in vitro bahan kering, bahan organik, dan protein kasar penggunaan klit buah jagung amoniasi dalam ransum 
ternak sapi. J. Ilmiah Ilmu-ilmu Peternakan. 13(5) : $252-259$.

Broudiscou, L. P., A. A. Dobnani, Y. Papon, A. Cornu, E. Grenet, and A. F. Broudiscou. 2003. Rice straw degradation and biomass synthesis by rumen micro-organisms in continuous culture in response to ammonia treatment and legume extract supplementation. Animal Feed Science and Technology. $105: 95-108$.

Chizzotti, F. H. M., O. G. Pereira, L. O. Tedeschi, S. C. V. Filho, M. L. Chizzotti, M. I. Leao and D. H. Pereira. 2008. Effects of dietary nonprotein nitrogen on performance, digestibility, ruminal characteristics and microbial efficiency in crossbreed steers. J Anim Sci. 86 : $1173-1181$.

Church, B.C. 1988. The Ruminant Animal, Digestive Phisiology and Nutrition. $3^{\text {td }}$ ED. Prentice Hall Division of Simon Schuster EnglewoodCliffs, New Jersey.

Darwis, A. A. dan E. Sukara. 1990. Teknologi Mikrobial. Departemen P dan K. Dirjen Pendidikan Tinggi.PAU Bioteknologi.Institut Pertanian Bogor.

Meng, Q. X., Z. G. Xia and M. S. Kerley. 2000. The requierment of ruminal degradable protein for non structural carbohydrat fermenting microbices and its reaction with dilution rate in continuous culture. Asian-Aus J. Anim. Sci. 13(10) : 1.399 1.406.

Muslim, G., J. E. Sihombing, S. Fauziah, A. Abrar dan A. Fariani. 2014. Aktivitas proporsi berbagai cairan rumen dalam mengatasi tannin dengan tehnik in vitro. Jurnal Peternakan Sriwijaya. 3 (1) : $25-36$.

Orskov, E. R. 1982. Protein Nutrition in Ruminants. Academic Press, London.

Plummer, D. T. 1971. An introduction to practical biochemistry. McGraw-Hill Publ., London.
Rahmadi, D., Sunarso, J. Achmadi, E. Pangestu, A. Muktiani, M. Christiyanto, Surono dan Surahmanto. 2010. Ruminologi Dasar. Fakultas Peternakan Universitas Diponegoro, Semarang.

Suhada, A.T., L. K. Nuswantara, E. Pangestu, F. Wahyono and J. Achmadi. 2016. Effect of synchronization of carbohydrate and protein supply in the sugarcane bagasse diet on microbial protein shyntesis in sheep. J. Indonesian Trop. Anim. Agric. $4(1): 135-144$.

Suhartanto, B., Kustantinah dan S. Padmowijoto. 2000. Degradasi in sacco bahan organik dan protein kasar empat macam bahan diukur menggunakan kantong inra dan rowett research institute. Buletin Peternakan. 24(2) : $82-93$.

Suryadi. 2008. Pengaruh suplementasi daun sengon (Albazia falcataria) terhadap kecernaan dan fermentabilitas. J. Ilmiah Ilmu-ilmu Peternakan. 11(2) : $93-98$.

Sutardi, T. 1980. Landasan Ilmu Nutrisi. Departemen Ilmu Makanan Ternak. Fakultas Peternakan. Institut Pertanian Bogor, Bogor.

Syahrir, N. Asmudin, M. Zain, I. Rohmiyatul, A. Anie. 2012. Optimalisasi Biofermentasi Rumen guna Meningkatkan Nilai Guna Jerami Padi sebagai Pakan Sapi Potong dengan Penambahan Biomassa Murbei dan Urea Mineral Moalasses Liquid (UMML). Universitas Hasanuddin. Makassar.

Tilley, J.M. A. and R. A. Terry. 1963. A two stage technique for the in vitro digestion of forage. J. British Grassland Soc. $18: 104-111$.

Zain, M., Elihasridas, dan D. Mangunwidjaja. 2005. Pengaruh suplementasi daun ubi kayu terhadap fermentabilitas dan kecernaan in vitro ransum berpakan serat sawit hasil amoniasi dengan urea. J. Tek. Ind. Pert. $15(2): 54-59$. 